\title{
Correction to: Ganga river water quality assessment using combined approaches: physico-chemical parameters and cyanobacterial toxicity detection with special reference to microcystins and molecular characterization of microcystin synthetase ( $\mathrm{mcy}$ ) genes carrying cyanobacteria
}

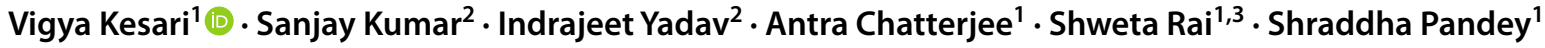 \\ Published online: 5 October 2021 \\ (c) Springer-Verlag GmbH Germany, part of Springer Nature 2021
}

Correction to: Environmental Science and Pollution Research https://doi.org/10.1007/s11356-021-16589-1

The last digit of third gene sequence number is needed to be change to 6 instead of 4 .

Gene bank accession ID numbers are MZ222414, MZ222415, and MZ222416 for mcyE, mcyA, and mcyB genes, respectively.

Publisher's note Springer Nature remains neutral with regard to jurisdictional claims in published maps and institutional affiliations.

The original article can be found online at https://doi.org/10.1007/ s11356-021-16589-1.

Vigya Kesari

vigya.kesari10@bhu.ac.in; vigyakesari@gmail.com

1 Centre of Advanced Study in Botany, Institute of Science,

Banaras Hindu University, Varanasi 221005, India

2 School of Biochemical Engineering, Indian Institute of Technology (BHU) Varanasi, Varanasi, U.P, India

3 Department of Botany, Braj Mohan Das College (B.R. Ambedkar Bihar University), Vaishali, Bihar, India 